\title{
FOLKLÓRNE PRVKY V KOMPONOVANEJ HUDBE A ICH REFLEXIA V SLOVENSKOM KONTEXTE
}

\author{
KRISTÍNA GotTHARDTOVÁ
}

Mgr. Kristína Gotthardtová DiS. Art; Ústav hudobnej vedy SAV, Dúbravská cesta 9, 84104 Bratislava 4; e- mail: kristina.gotthardtova@savba.sk

\section{Abstract}

\begin{abstract}
The utilization of folklore elements in composed music was explored by Slovak musicologists and composers during the nineteenth and the twentieth centuries. Their views were published in monographs, historical syntheses, studies, and essays in periodicals and journals. Perspectives on the selection of folklore models and on the way of their utilization in musical compositions kept changing according to the various historical periods and the contemporaneous social and cultural situation. This study presents an overview of the perspectives of Slovak musicologists and composers on this issue within three concepts of working with folklore models: an aesthetic, a historical, and a theoretical-analytical one.
\end{abstract}

Keywords: folklorism, composed music, reflection, nationality in music

Folklórne inšpirácie v hudobnej tvorbe 20. storočia boli dôležitou súčastou štýlových orientácií a estetických smerov v mnohých európskych regiónoch vrátane Slovenska. Úvahy o tom, čo skladatel'ov viedlo k využívaniu ludových hudobných prvkov v komponovanej hudbe a ako s týmito prvkami pracovali, boli predmetom muzikologického výskumu aj dobovej umeleckej kritiky. Problematika spracovania ludovej hudby bola reflektovaná najmä z troch hladísk - estetického, historického a teoretického. Ťažiskom tohto textu je zhodnotenie domácej reflexie zaoberajúcej sa problematikou folklórnych inšpirácií v hudobnej tvorbe domácich skladatelov. Dôležitým zdrojom informácií sú aj vyjadrenia samotných skladatelov, pretože cez pochopenie ich kompozičného vztahu k ludovej hudbe sa dá lepšie pochopit’ aj ich hudobná tvorba. Nadväzovanie na hudobný folklór sa realizovalo i v hudobnej tvorbe autorov iných krajín, preto sa v oblasti hudobnej teórie opierame aj o práce medzinárodného kontextového významu. 
Problematika folklórnych inšpirácií v komponovanej (umeleckej) hudbe zahŕňa viacero hladísk, ktoré sa navzájom prelínajú. Napriek tomu sa v doterajšej reflexii dajú vymedzit tri základné hladiská, ktoré v jednotlivých prácach prevažovali ako tažiskové alebo dominujúce.

\section{Aspekty hudobnej estetiky}

Na Slovensku otázka kompozičného spracovania folklórnych prvkov osobitne rezonovala v prácach, ktoré vznikali na pozadí dobových polemík týkajúcich sa širšej umelecko-estetickej orientácie domácej hudobnej tvorby. Táto otázka často súvisela s názormi na podstatu národnej hudby a na vztah regionálnych, národných a univerzálnych prvkov $\mathrm{v}$ hudobnej tvorbe.

K prvým kritickým názorom na podstatu slovenskej hudby patrí príspevok hudobného skladatela Jána Levoslava Bellu z roku 1873, uverejnený v Letopise Matice slovenskej. V tomto príspevku prezentoval svoje postoje $\mathrm{k}$ formovaniu národnej hudby. J. L. Bella si uvedomoval dôležitost’ spoločenskej funkcie hudby a zároveň chápal, že ak má poslucháčske publikum hudbu prijat’ a oblúbit si ju, musí jej porozumiet. Do svojej názorovej koncepcie preberal idey štúrovskej generácie a v národnej orientácii videl predpoklad vzniku velkej slovanskej hudby, ktorá by bola so svojimi špecifikami odvodenými z ludovej hudby dôležitou opozíciou voči silnej románskej a germánskej tradícii. J. L. Bella upozorňoval, že skladatelia a hudobníci pri úpravách „násilne premieňajú, kazia a ničia národnie melodie“, ${ }^{1}$ kedže sa držia zásad modernej teórie. Všimol si, že ludoví speváci v piesňach intonujú niektoré intervaly z tohto hladiska „nečisto“, čo zapisovatelia piesní v modernej notácii nereflektujú: „[...] potom sa stáva, že spevy slovenské národniu svoju pôvodnost' tratia. “2 Bella okrem toho nabádal na vytvorenie zborníka piesní slovanských národov - na základe zozbierania a následného analyzovania nápevov by sa dala vymedzit charakteristika spoločných znakov, ktoré by mohli po akceptovaní hudobnými skladatel'mi podnietit rozvoj slovanskej hudby. $\mathrm{Na}$ konci svojho článku Bella hovoril o zbieraní spevov a hier, aj o ich kritickej analýze. Uvedomoval si, že zber materiálu si vyžaduje výskum v teréne a je časovo i odborne náročný, preto v závere odporúčal, aby sa tejto úlohy ujala inštitúcia, ktorá by takúto zberatelskú akciu zorganizovala. J. L. Bella odvodil vznik národnej slovenskej, resp. slovanskej hudby priamo $\mathrm{z}$ hudby ludovej. Opodstatnenost' svojej idey videl najmä $\mathrm{v}$ tom, že hudba môže pôsobit na poslucháča (lud/národ) intenzívnejšie, ak mu bude myšlienkovo i hudobne blízka.

Na Bellove názory priamo zareagoval až v roku 1948 skladatel’ a hudobný teoretik Oto Ferenczy. Vo svojom príspevku prednesenom na I. zjazde skladatelov a hudobných vedcov Československa určil typické znaky slovenskej hudobnosti. Vo vývine slovenskej hudby videl dve základné estetické orientácie, ktoré sa presadili po sebe v nasledujúcich historických obdobiach. Prvá estetická orientácia sa spája s obdobím do prvej svetovej vojny, ked' hudobný skladatel' J. L. Bella vychádzal z hudobného ro-

BELLA, Ján Levoslav: Myšlienky o vývine národnej hudby a slovenského spevu. In: Hudobnovednýsborník, roč. 1, 1953, s. 28.

2 Tamtiež, s. 43. 
mantizmu, pričom zároveň jeho tvorbu determinovali požiadavky prostredia. Kedže Bella nemohol nadviazat na domácu kompozičnú tradíciu, preberal mimoslovenské prvky, ktoré si prispôsobil, a tak vytvoril modernejšie estetické normy. Po prvej svetovej vojne nasledovalo obdobie, ked' sa formovala druhá tradícia slovenskej hudby, ovplyvnená kompozičnou školou Vítězslava Nováka. Na jednej strane nadväzovala na folklórne predlohy, na druhej strane „následky spoločenského rozpoloženia slovenského života, svojráz oblasti mimoludskej stal sa stredobodom záujmu skladatelov orientovaných impresionisticky. ${ }^{\text {"3 }}$ O. Ferenczy upozornil, že nadväzovanie na hudobný impresionizmus má dve príčiny. Po prvé, prezentoval sa ako vztah k prírode a po druhé, vdaka jeho harmonickému a metricko-rytmickému mysleniu bolo možné v týchto intenciách vol’nejšie kompozične pracovat' so slovenskou ludovou piesňou. Zároveň O. Ferenczy pripomínal, že skladatelia vo svojej tvorbe berú do úvahy aj percepčné možnosti poslucháča. Konštatoval tiež, že mnohí autori ešte nevyčerpali všetky „tvárne možnosti“, ktoré by prekračovali hranice prijímania hudby u poslucháčov.

O desatročie neskôr muzikológ a hudobný skladatel' Ladislav Burlas uverejnil príspevok, v ktorom sa vracia k problému národnosti v hudbe, keď̌e hudba sa „neustále vyvíja a každá generácia ho musí riešit’ vždy nanovo. " ${ }^{4}$ Po J. L. Bellovi, ktorý syntetizoval medzinárodné kompozičné postupy s domácimi prvkami (pričom prevažovali vonkajšie vplyvy), L. Burlas videl posun v tvorbe Mikuláša Schneidra-Trnavského. Tomuto autorovi sa podarilo pozdvihnút úroveň úprav ludových piesní na vyšší vývojový stupeň, vd’aka čomu sa začali jeho piesne uvádzat’ aj na zahraničných pódiách. Ďalšia generácia skladatelov slovenskej hudobnej moderny sa usilovala syntetizovat národné prvky s internacionálnymi v novej estetickej orientácii. Na základe poznania zahraničnej hudby a autorov ako bol Igor Stravinskij, Vítězslav Novák, Leoš Janáček, Béla Bartók či Karol Szymanowski, si skladatelia vyberali hudobné prvky, s ktorými sa dala kompozične skĺbit slovenská ludová hudba. Napríklad, u Dezidera Kardoša nachádzame Bartókove vplyvy v harmonicko-melodickej oblasti, u Jozefa Kresánka bartókovskú rytmiku. Ján Cikker a Eugen Suchoň prejavili spoločný príklon k podhalanskej stupnici a tradičnej zbojníckej kultúre, podobne ako pol’ský skladatel' Szymanowski. „Novoromantická monumentalita, prejavujúca sa $v$ snahe o velké dynamické oblúky a o velké formové útvary“, ale i prítažlivost' impresionizmu, ktorá bola „aj v skutočnosti, že tento štýl využíval modálne harmónie, čím umožnil využitie charakteristických tónin starších vrstiev slovenskej ludovej piesne “5 - toto všetko nachádzame v tvorbe slovenských skladatel'ov. L. Burlas upozorňoval aj na rokmi nadobudnutý „automatizmus“ národného štýlu, pre ktorý sa v zahraničí javí naša hudba nad’alej konzervatívna a zameraná jednostranne. V príspevku odkazuje vrstovníkom-skladatelom, že „slovenská hudba vo svojom d’alšom vývoji musí si sformovat svoje konkrétne stanovisko k novším výdobytkom svetovej hudobnej kultúry, " ${ }^{\text {"6 }}$ pričom nie je nutné preberat' všetko, ale je potrebné si z nových možností triezvo vyberat'. Skladatel' by sa mal usilovat’ o nové vide-

3 FERENCZY, Oto: Pohlad na obecnú a sociálnu podmienenost' slovenskej hudby. In: Hudební rozhledy, roč. 1, 1948, č. 2-3, s. 32.

4 BURLAS, Ladislav: Myšlienky o vývine národnej hudby. In: Slovenská hudba, roč. 1, 1957, č. 2, s. 54.

5 Tamtiež, s. 58.

6 Tamtiež, s. 60. 
nie tradície. Mal by ju transformovat', pričom by mal predchádzat skĺznutiu do „aranžérskych manier" a zároveň by nemal štýlovo necitlivo narábat's ludovou predlohou. ${ }^{7}$

Ešte aj v roku 1964 reagoval na myšlienky J. L. Bellu muzikológ a hudobný skladatel’ Jozef Kresánek. Vo svojom príspevku v časopise Slovenská hudba uverejnil polemickú úvahu o tom, ako by mala vyzerat národná hudba. Zamýšlal sa hlavne nad estetickou hodnotou diel, nakolko táto hodnota je trvalejšia než aktuálna hodnota či hodnota národná. „Celá problematika národnej hudby je takto v podstate otázkou adresnosti, a nie v konkrétnych riešeniach iba nadväzovania na ludové prvky, ako sa často myslí." Zdôraznil, že slovenskí skladatelia by sa nemali uzatvárat pred medzinárodným kultúrnym dianím, ale mali by kriticky preberat prínosné prvky. $\mathrm{V}$ tvorbe slovenských skladatel'ov videl viaceré zmeny myslenia v narábaní s folklórnymi idiómami. Zatial čo v 30. rokoch sa skladatelia viac inšpirovali V. Novákom a jeho romantickejšou zvukovostou, v 50. rokoch začali vnímat koncepciu B. Bartóka, ktorý „to ludové nechcel dotvárat ako Novák, ale rozanalyzoval ho až na rytmické a tonálne bunky a $z$ tých od základov samostatne tvoril." ${ }^{\text {"9 }}$

Uvedené práce, články a úvahy spája skutočnost', že folklórne inšpirácie v hudobnej tvorbe domácich autorov hodnotili nielen $\mathrm{z}$ kompozično-technického hladiska, ale aj z pohladu hudobnej estetiky. Ich autormi boli hudobní skladatelia (J. L. Bella), ako aj skladatelia-muzikológovia (O. Ferenczy, L. Burlas, J. Kresánek). Prvotným zámerom vzniku týchto príspevkov bola reflexia aktuálnej dobovej hudobnej tvorby a snaha o jej usmernenie prostredníctvom sformulovania jej nového estetického programu.

\section{Práce z oblasti hudobnej historiografie}

Otázkou folklórnych inšpirácií v slovenskej hudobnej tvorbe 20. storočia sa dosial' $\mathrm{v}$ najväčšej miere zaoberali práce $\mathrm{z}$ hudobnej historiografie, s prípadnými presahmi do oblasti hudobnej teórie a analýzy. Problematika využitia folklórnych prvkov v komponovanej hudbe sa stala dôležitou súčastou hudobnohistorických syntéz dejín slovenskej hudby, knižných monografií, a najmä súčastou mnohých štúdií, článkov a príspevkov publikovaných $\mathrm{v}$ časopisoch a tematických zborníkoch.

Pohlad na hudobnofolklórne inšpirácie v kontexte vývoja slovenskej hudby a hudobnej kultúry prinášajú dve tažiskové hudobnohistorické syntézy. Vo vydaní Dejín slovenskej hudby z roku 1957 sa problematike slovenskej hudby 20. storočia venoval Zdenko Nováček. V kapitolách „Rozvoj hudobného života a zápas o modernú orientáciu slovenskej hudby v samostatnom štáte“ a "Rozkvet slovenskej národnej hudby po vítazstve národnej demokratickej revolúcie“ prináša stručnú charakteristiku obdobia do polovice 20. storočia. Z. Nováček upozorňoval na to, že vývoj slovenskej hudby bol limitovaný najmä možnostami vzdelávania slovenských skladatelov, ktorí boli dlhší čas viac-menej autodidaktmi. Kladne hodnotí kompozičnú prácu Mikuláša Moyzesa,

BURLAS, Ladislav: Etika a estetika slovenskej národnej hudby. In: Slovenská hudba, roč. 8, 1964, č. 6, s. 166 .

8 KRESÁNEK, Jozef: Opät myšlienky o národnej hudbe. In: Slovenská hudba, 1964, roč. 8, č. 6, s. 161.

9 Tamtiež, s. 163. 
Viliama Figuša-Bystrého a Mikuláša Schneidra-Trnavského, ktorí „hlboko načreli do pokladov slovenskej ludovej piesne, no nezostali pri jej citácii, ale rozvinuli muzikálnost' slovenského ludu do väčších a náročnejších foriem. "10 Vhodné smerovanie vývoja slovenskej hudby po roku 1945 podla neho nastane, ak sa hudobní skladatelia viac priblížia ludu a zbavia sa novodobých „nezdravých vplyvov“. Takéto tvrdenia poukazujú na vnášanie ideologických postojov do hodnotenia umeleckej tvorby, ale aj na primalý časový odstup na sformovanie objektívnejšej reflexie hudobnej tvorby súčasníkov.

Náhlad na stav hudobného života na Slovensku v 20. storočí prinášajú po takmer štyridsiatich rokoch zatial' posledné syntetické Dejiny slovenskej hudby od najstarších čias po súčasnost' (1996). Vývoj hudobného myslenia a hudobnej tvorby prvej polovice 20. storočia reflektoval Ladislav Burlas. Upozornil, že v tomto období bola čast’ aktívnych skladatelov stále pod vplyvom ideí národného obrodenia presahujúcich z 19. storočia. Vyššie kompozičné a umelecké kvality priznal trojici autorov M. Moyzes - V. Figuš-Bystrý - M. Schneider-Trnavský. Vdaka budovaniu domácich hudobných a hudobno-pedagogických inštitúcií vznikli predpoklady na formovanie profesionálneho hudobného umenia na Slovensku v oblasti kompozície, interpretačného umenia, ale aj muzikológie. L. Burlas poukázal na to, že mladí autori generácie slovenskej hudobnej moderny (A. Moyzes, E. Suchoň, J. Cikker) vnímali rozdiel medzi populárnou piesňou mestského prostredia a ludovou piesňou tradičného rol’níckeho a pastierskeho prostredia na Slovensku s bohatstvom starších štýlových vrstiev. „Inšpirácia ludovou hudbou v spojení s postimpresionistickým hudobným jazykom sa stala jednou $z$ charakteristických čŕt novovznikajúcej tvorby. "11 L. Burlas upozornil aj na to, že intenzívnejší kontakt so zahraničím a prenikanie neofolkloristických tendencií do dobovej kompozičnej tvorby podporili u slovenských skladatel’ov snahy o syntézu hudobných inšpirácií z domácich zdrojov aj z medzinárodného kontextu. „Kryštalizácia štýlu slovenskej hudobnej moderny sa vyznačuje nielen rozchodom s neskororomanticky chápanou chromatikou, ale i príklonom k modálne chápanej diatonike. " 2 Rozšírenie diatonického priestoru, využívanie akordov vyšších terciových štruktúr a modalita poskytli slovenským skladatelom nové možnosti spracovania folklórneho materiálu.

V nadväzujúcej kapitole „Vývoj po roku 1945“ Lubomír Chalupka vymedzil premeny slovenskej hudby v kontexte dobových spoločensko-historických okolností a na pozadí etnologicko-antropologických kategórií identity a akulturalizácie. Hudobní skladatelia sa začleňovali do celoeurópskeho priestoru, preto $\mathrm{v}$ ich tvorbe môžeme vnímat’ snahy jednak o sebaidentifikáciu, jednak o akulturalizáciu. „Štádiá priebežnej sebaidentifikácie a sebarealizácie sa viazali na pripomínanie a tvorivé prehodnocovanie zdrojov vlastnej hudobnej tradície, uložených tak $v$ špecifických štrukturálnych a intonačných vlastnostiach slovenského piesňového a tanečného folklóru, ako aj v afinite ku

10 NOVÁČEK, Zdenko: Charakteristika obdobia. In: BURLAS, Ladislav - MOKRÝ, Ladislav - NOVÁČEK, Zdenko (ed.): Dejiny slovenskej hudby. Bratislava : Vydavatel'stvo slovenskej akadémie vied, 1957, s. 341.

11 BURLAS, Ladislav: Slovenská hudba 20. storočia. Vývoj v prvej polovici storočia. In: ELSCHEK, Oskár (ed.): Dejiny slovenskej hudby. Od najstarších čias po súčasnost'. Bratislava : Ústav hudobnej vedy Slovenskej akadémie vied; ASCO Art \& Science, 1996, s. 265.

12 Tamtiež, s. 266. 
konkrétnym výrazovým polohám, námetovým okruhom, citovým reakciám a umelecko-tvorivým zámerom. " ${ }^{13}$ Postupné uvolnenie dobového ideologického vplyvu na umenie v priebehu druhej polovice 20. storočia poskytlo väčší priestor na individuálnu umeleckú sebarealizáciu a slovenskí skladatelia čerpali podnety z ludovej hudby len na základe vnútornej potreby a vlastnej estetickej koncepcie.

Problematika spracovania slovenského hudobného folklóru v kompozičnej tvorbe sa reflektovala aj v užšie zameraných tematických monografiách. V polovici 20 . storočia vznikli dve publikácie zamerané na zhodnotenie aktuálneho stavu slovenskej hudobnej tvorby. Jednou z nich je monografia Súčasná slovenská hudba od Ernesta Zavarského z roku 1947. Táto práca sa zaoberá vývojom slovenskej hudby prvej polovice 20. storočia. Autor v nej analyzoval tvorbu autorov slovenskej hudobnej moderny, ale detailnejšie sa otázkam využitia hudobného folklóru v ich dielach nevenoval. V závere kapitoly o Eugenovi Suchoňovi sa však dotkol vztahu skladatel’a k slovenskej ludovej piesni a položil si otázku, $\mathrm{v}$ čom tkvie slovenskost hudby tohto autora. Zvažoval, či ide o časté využívanie určitých intervalov alebo o vedenie melodických línií, ale pri analýze jeho hudby nevedel odhalit faktory, ktoré túto slovenskost' vytvárajú. Pri úvahách o hudobnej tvorbe Jána Cikkera zdôraznil, že hudobné myslenie tohto skladatela je spontánne preniknuté „prvkami melosu a rytmu slovenskej hudby" a jeho hudba je "syntézou moderných skladatel'ských prostriedkov s duchom ludovej hudby slovenskej. " Inklináciu k ludovej hudbe si všimol aj v ranej tvorbe Dezidera Kardoša a tiež u Jozefa Kresánka, ktorý tvoril „z ducha ludového tanca a ludovej piesne pôvodné diela“15.

Druhou monografickou prácou je Súčasná slovenská hudobná tvorba (1955) od Zdenka Nováčka. Autor sa venoval vymedzeniu kritérií na posudzovanie dobovej autorskej tvorby a aplikoval ich pri analýzach vybraných diel súčasných slovenských skladatelov. Výber reprezentatívnych kompozícií naplñajúcich dané kritériá sa však zdá byt poznačený dobovou ideológiou. $V$ súvislosti s generáciou slovenskej hudobnej moderny zdôraznil, že jej autorom pripadla úloha „dovrśsit doterajší vývoj, rozvinút nastolené realistické princípy v hudbe svojich predchodcov, obohatit techniku o plne využitý odkaz klasickej a zdravej poklasickej hudby, naplnit moderný pojem národnosti a rozvinút svoju tvorbu do všetkých potrebných žánrov. "16 Čerpanie hudobného materiálu $\mathrm{z}$ folklórneho prostredia sa teda $\mathrm{v} 50$. rokoch 20 . storočia od skladatelov programovo očakávalo. V kapitole o tvorbe pre súbory ludovej umeleckej tvorivosti (t. j. aj folklórne súbory) Z. Nováček vyzdvihol skladatelov, ktorí sa venujú práve tvorbe pre tieto telesá: „Sú to drobní a zaslúžili remeselníci, ktorí vedia dat ludovej piesni jej správny, prostý harmonický a inštrumentálny kabát, ako aj tieto kvality umelecky sčasti rozvinút." "17 Folklorizmus sa v tomto období chápal ako nástroj, ktorý pomáhal hlbšie preniknút

13 CHALUPKA, Lubomír: Vývoj po roku 1945. In: ELSCHEK, Oskár (ed.): Dejiny slovenskej hudby. Od najstarších čias po súčasnost'. Bratislava : Ústav hudobnej vedy Slovenskej akadémie vied; ASCO Art \& Science, 1996, s. 273.

14 ZAVARSKÝ, Ernest: Súčasná slovenská hudba. Bratislava : Ernest Závodský, 1947, s. 82.

15 Tamtiež, s. 119.

16 NOVÁČEK, Zdeněk: Súčasná slovenská hudobná tvorba. Bratislava : Slovenská akadémia vied, 1955, s. 27.

17 Tamtiež, s. 347. 
k mysleniu ludu (vyrastal z jeho vedomia) a bol základným stavebným prvkom kompozícií, ktoré museli zapadat do rámca ideí socialistického realizmu.

V roku 1964 vyšla práca Slovenská hudba v profiloch a rozboroch, ktorá približuje slovenskú hudobnú tvorbu od konca 19. storočia až do začiatku 60. rokov 20. storočia. Jej autor Ivan Hrušovský rozšíril dovtedy mapovanú hudobnú tvorbu o dalších autorov, skladatelov najmladšej generácie. Venoval sa autorom starších generácií skladatelov, ale aj autorom nastupujúcej generácie - odchovancom kompozičnej školy A. Moyzesa a J. Cikkera. Publikácia poskytuje stručný súpis ich kompozičného diela a analýzu vybraných kompozícií týchto autorov. I. Hrušovský poukázal na skutočnost', že generácia A. Moyzesa, V. Figuša-Bystrého a M. Schneidra-Trnavského „predstavovala logické ohnivko $v$ historickom vývoji slovenskej hudby, tvorila pevný prechod $z$ diletantskej kultúry minulého storočia $k$ slovenskej avantgarde a pripravovala jej pôdu - napriek tomu, že mladí slovenskí skladatelia išli ideove a umelecky novými, odlišnými cestami. ${ }^{\text {"18 }}$ Pripomenul, že mladá generácia chce svoju hudbu aktualizovat a zároveň chce spojit nové kompozičné podnety so slovenskou tradíciou. Pri charakteristike vybraných skladieb bližšie špecifikoval, z akých folklórnych podnetov skladatelia čerpali (napríklad lúbostná, zbojnícka lyrika, baladickost'), aké prvky z hudobného folklóru využívali (rytmika, melodika, tonalita) a upozornil na programovost', ktorá tematicky vychádzala z ludovej kultúry (A. Moyzes). Pri charakteristike Suchoňovej hudobnej reči Hrušovský opísal cestu skladatela k originalite hudobného jazyka, ktorý sa formoval „zlúčením slovenskej ludovej melodiky s modernou kompozičnou technikou, predovšetkým s tzv. modálnym princípom, t. j. so systematickým výberom takého tónového materiálu, ktorý obsahujú charakteristické stupnice slovenských ludových piesni. " ${ }^{19}$ J. Cikker zas podla I. Hrušovského využíval ludové piesne a tance v novej podobe, pričom vychádzal $\mathrm{z}$ ich filozofickej podstaty. Poukázanie na význam čerpania prvkov z ludovej hudby nájdeme aj pri Hrušovského charakteristikách dalších slovenských skladatelov (Andrej Očenáś, Šimon Jurovský, Dezider Kardoš, František Babušek, Jozef Kresánek, Oto Ferenczy).

Monografia Ladislava Burlasa Slovenská hudobná moderna publikovaná v roku 1983 sa zameriava výhradne na jednu generáciu slovenských skladatelov, priblíženú v rámci jednej vývojovej etapy. Ide o generáciu autorov, ktorí reagovali na nové kompozičné smery v zahraničí, vdaka čomu sa im podarilo vymanit sa z vývojovej statickosti predchádzajúcej generácie. L. Burlas výstižne skonštatoval: „Generácia 30. rokov nedisponovala fundovanejšou vedeckou analýzou štýlových a štruktúrnych vlastností slovenskej ludovej piesne. Jednako si našla vývojovým podmienkam primeranú orientáciu a vlastné, priam inštinktívne triedenie hodnôt. ${ }^{\text {"20 }} \mathrm{V}$ poslednej kapitole s názvom "Celková charakteristika tvorby 30. rokov" podotkol, že skladatelia dostali myšlienky národnosti na kompozične profesionálnu úroveň. Vysvetlil pokračovanie národných tendencií tým, že slovenskí tvorcovia sa potrebovali začlenit medzi ostatné kultúrne národy a prejst' aj touto vývojovou fázou, i ked's určitým oneskorením. Upozornil na fakt, s ktorým sa domáce publikum nevyrovnalo dodnes: „doma sa prijíma [slovenská

18 HRUŠOVSKÝ, Ivan: Slovenská hudba v profiloch a rozboroch. Bratislava : Štátne hudobné vydavatel'stvo, 1964, s. 159.

19 Tamtiež, s. 194.

20 BURLAS, Ladislav: Slovenská hudobná moderna. Bratislava : Obzor, 1983, s. 44. 
hudba] ako primoderná a výbojná, kým v zahraničí sa jej avantgardný význam zväčša nepocituje. " ${ }^{21} \mathrm{~L}$. Burlas v monografii analyzoval vývojové štádiá slovenskej hudobnej moderny prostredníctvom hudobných skladieb a kompozičných prístupov. Upozornil na hudobno-žánrovú pluralitu, ktorá bola potrebná z hladiska dobového sociálno-kultúrneho zázemia. Slovenská moderna sa snažila o „odsentimentalizovaný postoj k folklórnemu dedičstvu a rovnako aj o odidealizované nazeranie na dedinu 20. a 30. rokov. ${ }^{\text {"22 }} \mathrm{Na}$ skladatel'ov vplývali aj dalšie inšpiračné faktory, napríklad sociálny rozmer hudby a prírodný i historický aspekt. Po hudobnej stránke sa zmenilo najmä chápanie systému harmónie, ktoré sa rozšírilo využívaním vyšších terciových štruktúr. Skladatelia sa v tomto období snažili ludovú pieseň zbavit nánosov a vplyvov pochádzajúcich od mestských cigánskych kapiel.

Novším príspevkom, ktorý zachytáva atmosféru prvej polovice 20. storočia v kontexte hudobno-teoretických a sociálnych aspektov, je publikácia Tradícia, modernost a slovenská hudobná kultúra (1996) od Nade Hrčkovej. Autorka v nej rozobrala viaceré činitele, ktoré priamo ovplyvňovali hudobný vývoj, tvrdenia podložila názormi skladatel'ov a teoretikov z dobovej literatúry a tlače. Pozornost' venovala aj teoretickému dielu hudobného skladatela Frica Kafendu, ktorý sa zaoberal slovenskou ludovou piesňou z hladiska melodickej a tonálnej výstavby, pričom spájal princípy hudobného myslenia slovenského ludu s harmonickými princípmi hudby 20. storočia. N. Hrčková poukázala aj na vplyv českých a moravských vzdelancov, ktorých idey ovplyvňovali vývoj slovenskej hudobnej tvorby.

Slovenskej hudbe 20. storočia a jej vývojovým premenám, vrátane osvojovania prvkov ludovej hudby, sa systematicky venoval vo svojich prácach L'ubomír Chalupka. Jeho príspevky vznikali synchrónne s tvorbou skladatelov, ktorú reflektoval od 70. rokov 20. storočia. Kedže bol súčasníkom generácie skladatelov nastupujúcich na začiatku druhej polovice 20. storočia, bol dobre oboznámený s dobovými ideologickými obmedzeniami umeleckej tvorby. Viaceré jeho knižné monografie (Slovenská hudobná tvorba po roku 1945, 1996; Slovenská hudobná avantgarda, 2011; Cestami k tvorivej profesionalite, 2015) sa zameriavajú na základnú charakteristiku aj detailnú hudobnú analýzu diel rovesníkov i predchádzajúcich generácií, ktorých postoje a prístupy hodnotil objektívne.

Vztah slovenských hudobných skladatel’ov k hudobnému folklóru približujú viaceré knižné monografie, venované vybraným skladatel'ským osobnostiam. Patrí k nim Ján Cikker (J. Šamko, 1955), Šimon Jurovský (Z. Bokesová, 1955), Dezider Kardoš (Z. Nováček, 1955), Alexander Moyzes (L. Burlas, 1956), Andrej Očenáš (M. Palovčík, 2002), Eugen Suchoň (J. Kresánek, 1961; E. Zavarský, 2008), Tadeáš Salva (M. Ščepán 2020). Tieto publikácie jednak zachytávajú dobové sociálno-kultúrne a umelecké aspekty, jednak analyzujú kompozície a hudobný jazyk skladatelov. ${ }^{23}$

21 Tamtiež, s. 165.

22 Tamtiež, s. 97.

23 ŠAMKO, Jozef: Ján Cikker. Bratislava : Slovenské vydavatel'stvo krásnej literatúry, 1955. BOKESOVÁ, Zdenka: Šimon Jurovský. Bratislava : Slovenské vydavatel'stvo krásnej literatúry, 1955. NOVÁČEK, Zdeněk: Dezider Kardoš. Počiatky a rast. Bratislava : Slovenské vydavatel'stvo krásnej literatúry, 1955. BURLAS, Ladislav: Alexander Moyzes. Bratislava : Slovenské vydavatel'stvo krásnej literatúry, 1956. PALOVČÍK, Michal: Andrej Očenáš. Hudobné ozveny domoviny. Brati- 
Dôležité poznatky ku kompozičnej práci s ludovou piesňou prinášali štúdie a články uverejnené v hudobných časopisoch, ktoré sa dotýkali aj smerovania slovenskej hudby. Ladislav Burlas a Ladislav Mokrý pre Slovenskú hudbu (1957) napísali spoločne sumarizujúci článok, ktorý v skratke analyzoval prínos zakomponovania ludovej hudby do klasických kompozícií. ${ }^{24}$ Príklon k využívaniu ludovej hudby v tvorbe generácie skladatel’ov 30. rokov považovali za „hladanie nového tvaru a výrazu“, nakol'ko brali do úvahy, že títo autori sa už hlbšie zaoberali hudobnou podstatou ludových piesní. Za základné ideové znaky hudby tejto generácie označili vlastenecké zameranie ich tvorby a príklon k tzv. realistickému stvárneniu, s ktorým kontrastujú romantické štýlové znaky (napríklad monumentalizmus). Aplikácia prvkov ludovej hudby (rytmus, melos, forma) na bázu umelej, komponovanej hudby priniesla rozvinutie jednoduchých foriem (úpravy piesní) do foriem náročnejších (symfonické básne, kantáty). Využívanie ludového materiálu bolo podmienené aj ideou morálnej zodpovednosti skladatela za celý národ, jeho hudba mala byt' rečou všetkých, mala hovorit’ o ich problémoch a vytvárat bezprostredný kontakt medzi skladatelom a poslucháčom. ${ }^{25}$ Vdaka využitiu elementov slovenskej l’udovej hudby si skladatelia formovali špecifický hudobný jazyk, ktorý bol rozpoznatelný aj v medzinárodnom kontexte.

Otázka uplatňovania prvkov hudobného folklóru v skladatel’skej tvorbe bola aktuálna aj v 60. rokoch, ked’ sa k renesancii národných tradícií v hudbe vyjadril Jozef Kresánek. ${ }^{26}$ Upozornil na fakt, že skladatelia sa po Februári 1948 začali vracat’ k lichardovskej tradícii, teda $\mathrm{k}$ tomu, čo už slovenská hudobná moderna prekonala. J. Kresánek prirovnal využívanie folklórnych elementov k „národnému maqam“, ktoré je prítomné v tvorbe skladatel’ov nadväzujúcich na hudobný folklór. Vyzdvihol variačný proces, ktorý je charakteristickým znakom l’udovej tvorivosti. Zároveň však upozornil, že nadväzovanie na folklór „ako na jedinú normu d’alšieho vývoja slovenskej národnej hudby" nemožno prikazovat'. Podotkol tiež, že pojem adresnost’ si nemožno zamieňat so zrozumitel'nostou a uplatňovanie folklórnych idiómov závisí predovšetkým od vzt̉ahu skladatela $\mathrm{k}$ folklóru.

Aktuálnost' využívania folklórnych prvkov v dobovej kompozičnej tvorbe sa odzrkadluje v ankete publikovanej v časopise Slovenská hudba v roku 1968. ${ }^{27}$ Oslovené osobnosti sa mali vyjadrit k piatim otázkam o kvalite, závažnosti a prístupoch $\mathrm{k}$ spracovaniu hudobného folklóru. Viacero skladatel’ov sa zmienilo o tom, že úpravy ludových piesní sú populárne, ale nie vždy sú dobre interpretované (tzv. reinterpretácia prostredníctvom mestských cigánskych kaviarenských kapiel). Jozef Grešák prirovnal ludové umenie $\mathrm{k}$ polnej kvetine, ktorá nepatrí do záhrady, čím apeloval na to, aby ludová hudba nestrácala svoju podstatu - spätost' so životom jej pôvodných nositelov.

slava : ARM 333, 2002. KRESÁNEK, Jozef: Národný umelec Eugen Suchoň. Bratislava : Slovenské vydavatel'stvo krásnej literatúry, 1961. ZAVARSKÝ, Ernest: Eugen Suchoň. Bratislava : Hudobné centrum, 2008. ŠČEPÁN, Michal: Tadeáś Salva. Život a dielo. Bratislava : Ústav hudobnej vedy SAV, 2020.

24 BURLAS, Ladislav - MOKRÝ, Ladislav: 40 rokov slovenskej hudby. In: Slovenská hudba, roč. 1, 1957, č. 8-9, s. 245-258.

25 Tamtiež, s. 258.

26 MARTON, Ivan: Profesor Kresánek o našom folklóre. In: Slovenská hudba, roč. 12, 1968, č. 5, s. 213-215.

27 [red.]: Anketa. In: Slovenská hudba, roč. 12, 1968, č. 5, s. 210-212. 
Čo sa týka vztahu skladatela k ludovej predlohe, Ladislav Burlas tu hovoril o „vyrovnanom partnerstve“, ktoré závisí od zámeru a tvorivého prístupu skladatela. Tiež upozornil na vývin názorov na spracovanie folklórnej predlohy, ktorý prebiehal na Slovensku od 19. storočia. Nový vývojový krok možno vidiet aj vo vzniku samostatného žánru ludovej hudby v úpravách pre súbory ludovej tvorivosti (folklórne súbory), ktorý je sekundárnou formou $\mathrm{k}$ paralelne prebiehajúcej, ústne tradovanej ludovej hudbe žijúcej v jej pôvodnom prostredí. Názory skladatelov na využívanie folklórnych prvkov v hudobnej tvorbe sú dôležitým zdrojom poznatkov z pohladu samotného tvorcu a predstavujú doplnok $\mathrm{k}$ muzikologickej reflexii tejto problematiky.

Tematické dvojčíslo Slovenskej hudby z roku 2005 sa venuje otázkam tradície, inovácie a modernosti vo vývojových premenách. Nakol'ko pojmy tradícia a modernost' sa v 20. storočí na domácej pôde chápali rôzne a ich používanie bolo nadužívané, je zaujímavé sledovat novšie polemiky muzikológov k ich významom. Podla Lubomíra Chalupku ,pojem, tradícia' sa vo vztahu $k$, modernému' ocitol na úrovni konzervatizmu, zaostávania umeleckého vývoja, alebo určoval určitý stabilizovaný okruh tvorivých motivácií $i$ výsledkov. ${ }^{{ }^{28}}$ Inovácia sa v určitých vývinových obdobiach 20 . storočia na Slovensku považovala za nevhodnú a nenáležitú najmä v kontexte dobovej ideológie - inovatívne hudobné štruktúry kolidovali s dobovým ideologickým nastavením a označovali sa ako škodlivé. Ideologický nátlak na skladatelov, aby bola ich hudba zrozumitel'ná širokým vrstvám obyvatelstva, neraz zdiskreditoval zámery čerpania inšpirácií z ludovej hudby.

Fenomén využitia hudobnofolklórnych prvkov v komponovanej hudbe sa reflektoval aj v širších historických, kultúrnych, štýlových a žánrových súvislostiach. Tematický zborník z medzinárodnej konferencie Národné, individuálne a univerzálne prvky v hudbe (1998 $)^{29}$ priniesol niekolko príspevkov, ktoré sa tohto fenoménu dotkli ako jedného $\mathrm{z}$ viacerých aspektov štúdia uvedených troch kategórií v hudbe. Editorka zborníka Jana Lengová poukázala nielen na ich historický, ale aj estetický, filozofický a sociálny rozmer. Zdôraznila, že „tri kategórie, prezentujúce národné, individuálne a univerzálne fenomény v umení, patria $k$ nosným faktorom, ktorých vztah, hierarchia a význam sú historicky podmienené. [...] Otázka národného prvku v hudbe, a stým súvisiaca otázka národnej hudby, stala sa predmetom nespočetných muzikologických štúdií. $V$ tomto zložitom a mnohovrstvovom probléme je však nanajvýs dôležité zdôraznit, že nejde o hodnotovú, ale o sociálnu, historickú a filozofickú kategóriu. ${ }^{\text {"3o }}$

\section{Hudobná teória a analýza}

V porovnaní s hudobnohistorickým bádaním vzniklo dosial podstatne menej prác, ktoré sa venovali otázke využitia hudobného folklóru na pôde komponovanej hudby

28 CHALUPKA, Lubomír: Inovačné procesy ako pojem a súčast' vývoja slovenskej hudby 20. storočia. In: Slovenská hudba, roč. 31, 2005, č. 3-4, s. 224.

29 LENGOVÁ, Jana (ed.): Národné, individuálne a univerzálne prvky v hudbe. Zborník príspevkov $z$ medzinárodnej muzikologickej konferencie. (=Bibliotheca Musicae Neosoliensis 3.) Banská Bystrica : Nadácia Jána Levoslava Bellu, 1998.

30 Tamtiež, s. 11. 
ako teoretickému problému, a to aj v medzinárodnom meradle. Len niekol'ko muzikológov sa touto otázkou zaoberalo z teoreticko-systematického hladiska, ked' sa pokúšali svoje poznatky zovšeobecnit a vymedzit rôzne stupne (roviny, úrovne, prístupy) využitia folklórnych prvkov v komponovanej (umeleckej, autorskej) hudbe. Niektoré koncepcie a definície opíseme na príklade vybraných prác a autorov.

V slovenskom kontexte sa možnostami využitia folklóru zaoberal Ladislav Burlas v monografii Hudobná teória a súčasnost' (1978), a to najmä v kapitolách „Vývoj kompozičnej techniky v súčasnej slovenskej hudbe“ a „Ludová hudba a skladatel“. V týchto dvoch kapitolách opísal historické i dobovo aktuálne hudobné trendy vo výstavbe melodiky, akordiky, rytmu i formy kompozícií: „V súčasnom vývoji sa zdá, že dochádza aj $k$ novému využívaniu tzv. tradičných akordických štruktúr, ktoré v hudobnom kontexte dostávajú nový význam. ${ }^{\text {"'31 }}$ Hudobní skladatelia využívajú klasické harmonické myslenie, ktoré môže vychádzat aj z luudových motívov, avšak kombinujú ho s aktuálnejšími kompozičnými technikami (zahustovanie akordov, polyfonické prepojenie hlasov, sonórnost). Poukázal aj na funkciu využívania folklórnych prvkov v umeleckej tvorbe: „Význam opierania sa o ludovú hudobnú tradíciu v umeleckej hudbe vidíme predovšetkým vo vedomom udržiavaní kontinuity $v$ národnej tradícii, $v$ tušenej či uvedomovanej dialektike vztahu tradície a nových umeleckých prínosov. ${ }^{\text {"32 }}$ Ďalej upozornil, že pri pracovaní s ludovou piesňou je potrebné folklórnu predlohu analyzovat’ a odkrývat' jej umelecké hodnoty. Skladatel’om z tzv. venčekárskeho obdobia vytýka ich mechanické aplikovanie durovo-molového harmonického systému pri spracovaní slovenských ludových nápevov a upozorňuje na potenciálnu farebnost', ktorá pramení z ich tonálnych osobitostí. Poukázal na význam tvorivého spracovania folklórnej predlohy: „Ak sa zjavilo stanovisko tzv. únavy z folklóru', na vine nie je tradícia [...], ale ide o manko na strane tvorivého prístupu $k$ tejto tradícii. ${ }^{{ }^{33} 3}$ Zdôraznil, že skladatel' by mal svoj tvorivý prínos a fantáziu usmernit tak, aby spracovanie folklóru nebolo konvenčné, ale aby malo svoje zvláštnosti. Skladatel' má rešpektovat osobitosti ludového prejavu, ale zároveň sa od neho čaká, že „do diela vnáša čosi nové, čo konvencia nepredpokladá, čo aktualizuje dielo a věleňuje ho do estetických hodnôt súčasnosti. ${ }^{\text {"34 }} \mathrm{V}$ súvislosti s kompozičným využívaním ludovej piesne a hudby upozornil na zmenu nositela a interpreta tradície, ktorým už nie je intuitívne premýšlajúci človek z tradičného prostredia slovenskej dediny, ale sú ním umelecké telesá (orchestre, zbory, ludové súbory). Dochádza teda $\mathrm{k}$ premene chápania funkcie folklóru, ktorý môže byt spracovaný v rozdielnych umeleckých rovinách, ktoré záviseli aj od adresáta kompozícií.

$\mathrm{Na}$ ilustráciu toho, ako sa dá s ludovou piesňou kompozične pracovat', L. Burlas uviedol niekol'ko kategórií prístupov z pozície hudobného skladatela: od kategórie úprav, ktoré sa rôznia obsadením a spôsobom práce s ludovou piesňou - od vokálnej hudby transponovanej do inštrumentálnej hudby, cez vokálnu hudbu štylizovanú do podoby klasického zborového spevu, umelú skladbu, ktorá chce pôsobit ako originálna ludová hudba, až po volnú fantáziu na ludové motívy. Tieto kategórie jasne poukazujú na niekol'ko základných skladatel’ských techník, ktoré sa využívali pri práci

31 BURLAS, Ladislav: Hudobná teória a súčasnost'. Tatran : Bratislava, 1978, s. 88.

32 Tamtiež, s. 136.

33 Tamtiež, s. 141.

34 Tamtiež, s. 141. 
s folklórnou predlohou: úprava, imitácia, štylizácia, transmutácia. Postupné sformovanie týchto techník bolo podmienené historickým vývojom od národnobuditelských a osvetovo zameraných úprav (tzv. venčekov) v podobe aditívneho radenia viacerých ludových piesní, cez kompozične náročnejšie montáže a suity ludových piesní až po technicky náročné symfonicko-vokálne cykly, ktoré už splňali náročné umelecké ambície. Podla L. Burlasa „Súčasná doba kladie na skladatela vystupňované záväznosti trojakým smerom: 1. smerom $k$ rešpektovaniu osobitosti ludovej hudby (vzhladom na rôzne hudobné dialekty, štýly a interpretačné techniky), 2. smerom k hudobnému jazyku našej doby a $k$ celkovej náročnosti kompozičnej práce, 3. smerom $k$ žánrovej špecifickosti skladieb inšpirovaných ludovou hudbou (symfonicko-vokálna tvorba, zborová hudba, súborová tvorba atd.)." ${ }^{\text {"35 }}$

Základnú typológiu práce s hudobnofolklórnym materiálom prezentovala na príklade štúdia hudobnej tvorby Dezidera Kardoša Hana Urbancová, pričom vychádzala zo spojenia hudobnej teórie a etnomuzikológie. ${ }^{36}$ Kompozičná tvorba jedného autora a inšpiračný zdroj v regionálne ohraničenej folklórnej tradícii umožnili autorke podrobnejšie vymedzit viaceré úrovne a stupne kompozičného spracovania ludovej piesne a definovat ich. Spôsob práce skladatela s ludovou piesňou rozdelila do niekolkých kategórií, pričom každú z nich doplnila o vybrané analýzy Kardošových diel. Na príklade kompozičnej práce s ludovou piesňou vyčlenila štyri základné typologické kategórie - adaptáciu, imitáciu, štylizáciu a transmutáciu. Tieto kategórie sa odvíjajú od postupného osamostatňovania sa skladatela od ludovej predlohy. Pri adaptáciách sa skladatel' viac-menej pridržiava folklórnej predlohy. Ludová pieseň sa v nej zobrazí $\mathrm{v}$ celku (cituje sa), avšak skladatel' k nej dokomponuje d’alšie hlasy, resp. nový hudobný materiál: „Adaptácia je vzhladom na použitý materiál dvojvrstevným útvarom, obsahujúcim jednak vlastnú ludovú pieseñ, jednak skladatelom dodanú látku. Rozlišujúcim kritériom, ktoré ju delí od d’alších stupňov, je využitie citátu konkrétnej ludovej piesne. ${ }^{{ }^{37}}$ Do tejto kategórie sa radia strofické i stroficko-variačné úpravy piesní, ktoré sú obohatené introdukciou, medzihrami či kódou. K adaptáciám patria aj prekomponované spracovania ludových piesní, v ktorých skladatel' zasiahol do textu alebo melódie ludovej piesne a pretvoril jej štruktúru. V prípade prekomponovaného spracovania je autorský prínos vyšší a väčší priestor dostáva individualita skladatela.

Ďalšie tri kategórie (imitácia, štylizácia, transmutácia) sa čoraz viac vzdalujú autentickej ludovej predlohe. Skladatel' si vyberá len isté typické regionálne alebo hudobno-vývojové špecifiká, ktoré v diele zdôrazní. Vybraný typický prvok je imitáciou, ak sa napodobňuje určitý folklórny útvar ako celok (napríklad nápev piesne), alebo môže byt štylizáciou, ak sa jeho vlastnost prenesie na plochu celej kompozície. Imitácia „predpokladá v istom zmysle približenie sa k spôsobu ludového myslenia [...] Skladatel" sa však nikdy úplne nestotožní s myslením ludového speváka, preto sa napriek snahe kombinovat charakteristické prvky dialektu nevyhne istej deformácii. To je dôkazom, že

\footnotetext{
35 Tamtiež, s. 154.

36 URBANCOVÁ, Hana: Tvorba národného umelca Dezidera Kardoša a východoslovenská ludová pieseň. [Diplomová práca.] Bratislava : Vysoká škola múzických umení, Hudobná fakulta, Katedra hudobnej teórie, 1980.

37 Tamtiež, s. 10.
} 


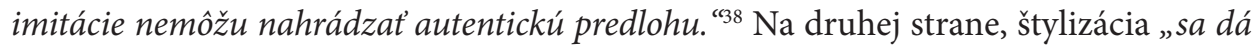
chápat ako prienik prvkov ludového myslenia a kompozičnej skúsenosti skladatela. "39 Pri transmutácii sa folklórny prvok stáva neoddelitel'nou súčastou skladatelovho hudobného myslenia, vplýva na melodický i metricko-rytmický obsah kompozície a zasahuje organizáciu vertikálnej i horizontálnej zložky skladby.

Markéta Štefková sa venovala využitiu prvkov ludovej hudby v kompozičnej tvorbe niektorých európskych skladatelov, pričom medzi ich prístupmi hladala aj určité paralely a vzájomné vplyvy. Vo svojich prácach spájala prístupy hudobnej teórie a analýzy a hudobnej historiografie. Na príklade nórskeho skladatel’a E. H. Griega si všímala prvky nórskej ludovej hudby vo vybraných kompozíciách tohto skladatela, ktoré boli prejavom národného štýlu v dobovej európskej umeleckej (komponovanej) hudbe. ${ }^{40}$ Osobitne sa zamerala na vplyvy nórskej ludovej inštrumentálnej hudby na Griegovu hudobnú reč. Sledovala využitie prvkov ludovej inštrumentálnej hudby v komponovanej hudbe, ktoré má svoje špecifiká v porovnaní s kompozičnou prácou s vokálnym folklórom a ludovou piesňou. Vychádzala pritom zo staršej typológie Bélu Bartóka z 30. rokov 20. storočia, ktorá rozlišuje tri rôzne spôsoby využitia folklórnych prvkov:

1. „priame prevzatie sedliackej melódie, bez akejkolvek zmeny alebo len s malou variáciou, ktorá je vybavená sprievodom a eventuálne obsahuje nejakú predohru a dohru“,

2. „skladatel nevyužíva nijakú pravú, sedliacku melódiu', ale namiesto toho vytvára sám určité imitácie sedliackych melódii",

3. „skladatel nevyužíva ani sedliacke melódie, ani ich imitácie, z jeho hudby však vyžaruje tá istá atmosféra ako zo sedliackej hudby. V tomto prípade možno povedat', že sa skladatel naučil hudobnú reč sedliakov a ovláda ju tak dokonale ako básnik svoj materinský jazyk. " 41

Náhlady na spôsob práce s folklórnou predlohou sa rôznili jednak historicky a jednak osobnostne. Každý skladatel' sa snažil osvojit’ si prácu s ludovým materiálom na základe vlastného postupu a podla vlastných princípov. Záujem o kompozičnú a umeleckú prácu s folklórnou predlohou pramenil z rôznorodých kultúrnych, spoločenských, estetických i politicko-historických daností, ktoré ovplyvňovali kvalitu i kvantitu využitia ludových prvkov na pôde komponovanej hudby.

Štúdia je súčastou grantového projektu VEGA č. 2/0145/18 „Systematika piesňových žánrov v tradičnej hudobnej kultúre“ (2018 - 2021), riešeného v Ústave hudobnej vedy SAV.

38 Tamtiež, s. 44.

39 Tamtiež, s. 48.

40 ŠTEFKOVÁ, Markéta: K využitiu prvkov ludovej hudby v umeleckej hudbe 19. a 20. storočia. Prvky „národného štýlu“ v klavírnych dielach Edvarda Griega. In: Slovenská hudba, roč. 40, 2014, č. 4, s. 311-333.

41 Tamtiež, s. 327. 